Nig. J. Anim. Prod. 2019, 46(2):47 - 54 Nigerian Journal of Animal Production

(C)Nigerian Society for Animal Production

\title{
Effects of aqueous leaf extract of Acalypha wilkesiana on semen morphology and characteristics in male Wistar albino rats
}

${ }^{1}$ Olukunle, J. O., ${ }^{2}$ Jacobs, E. B., ${ }^{1}$ Adeleye, O. E., ${ }^{1}$ Oyewusi, J. A., ${ }^{1}$ Adenubi, O. T. and ${ }^{1}$ Durotoye, L. A.

${ }^{1}$ Department of Veterinary Physiology and Pharmacology, College of Veterinary Medicine, Federal University of Agriculture, PMB 2240, Abeokuta, Ogun State.

${ }^{2}$ Department of Veterinary Medicine and Surgery,

College of Veterinary Medicine, Federal University of Agriculture, PMB 2240, Abeokuta, Ogun State.

Abstract * Correspondence author:drfaks@yahoo.com; 234-810-184-6078

To study the effect of the aqueous leaf extract of Acalypha wilkesiana (Euphorbiaceae) on some reproductive parameters of male Wistar albino rats, three groups $(A, B$ and $C)$ of six rats each were treated with 400, 800 and $1600 \mathrm{mg} / \mathrm{kg} /$ day of leaf extract of Acalypha wilkesiana, respectively for 28 days while $5 \mathrm{mLs} / \mathrm{kg}$ of distilled water was given to the control group D. At the end of the experimental period, animals were sacrificed and sperm characteristics, histology of the testes and epididymis were assessed. Sperm motility

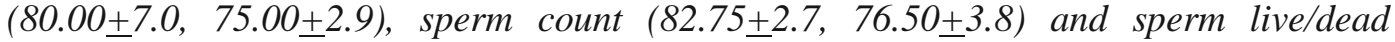
$(96.00 \pm 2.0,94.50 \pm 1.7)$ were not significantly reduced $(P<0.05)$ at the dosages of 400 and $800 \mathrm{mg} / \mathrm{kg}$ Acalypha wilkesiana leaf extract, respectively. did not have any significant reduction $(P<0.05)$ in, but significant $(P<0.05)$ reductions in sperm count $\left(71.50 \pm 3.5^{*}\right)$ was observed at $1600 \mathrm{mg} / \mathrm{kg}$ dose. Also, significant $(P<0.05)$ increase in morphological abnormalities of the spermatozoa were only observed in the $1600 \mathrm{mg} / \mathrm{kg}$ treated group of rats. Histopathological evaluation of the testis and revealed varying degrees of degeneration and necrosis of the germinal epithelia cell of the seminiferous tubules and spermiostasis, whereas no significant lesion was seen in the epididymis. The high dose of the leaf extract of Acalypha wilkesiana may have significant anti-spermatogenic effects on adult male Wistar rats.

Keywords: extract, leaf extract of Acalypha wilkesiana, rats, sperm.

Introduction activity effective in treating eczema, andTinea Acalypha wilkesiana also called copperleaf pedis, Pityriasis versicolor, Candida intetrigo, or Jacob's coat and 'jinwini, eela or Impetigo contagia and Tinea coporis infections aworoso' among the Yorubas of West (Oyelami et al., 2003). It exhibits antitumor and Africa, belongs to the plant family antiinflammatory activities when used in Euphorbiaceae and is a large fast growing combination with other plants, as employed evergreen coarse textured shrub whose empirically by traditional healers in southwest heart shaped leaves are available in varying Nigeria to treat breast tumors and inflammation mottled color combinations of green, (Bussing et al., 1999). A. wilkesiana has purple, orange, pink or white. hemolytic activities in vitro and has been used Historically believed to be a native of Asia, as antihypertensive agent with diuretic it has been reported with pain killing properties (Kokko, 1984; Ikewuchi et al., activities (Burkhill, 1985), antidiarrheal 2008). Recently it has also been reported that (Oluyemi et al., 1998), antimicrobial the chemical activities against gram +ve bacteria and other species of bacteria (Akinyemi et al., 2006). It is also claimed to have antifungal 47 


\section{Antispermatogenic activity of leaf extract of Acalypha wilkesiana}

constituents of the crude extracts of this wilkesiana on sperm parameters. This study plant has antiplasmodial effects along with was therefore carried out to investigate the analgesic activities (Udobang et al., 2009). effects of the administration of aqueous leaf Alkaloids, tannins, saponins, flavonoids, extract of Acalypha wilkesiana on the sperm anthraquinones and glycosides have been characteristics and morphology of male Wistar reported to be some of the phytochemical rats.

constituents of this plant (Akinyemi et al.,

2006; Oladunmoye, 2006; Hirano et al., Materials and methods Animal 1989). In addition, Akinde (1986) and management

Adesina et al. (2000) have also reported Twenty-four adult male Wistar rats weighing presence of Gallic acid, corilagin, gerenin, between 170-200g were used for this study. quercetin 3-0 rutinoside, sequiterpenes, The rats were housed in the Experimental monoterpenes, triterpenoids and Animal Unit of the College of Veterinary polyphenols. Medicine, University of Agriculture, There have been various reports on the Abeokuta, Ogun State, Nigeria. They were kept antispermatogenic and antifertility effect in well-ventilated metal cages at ambient of antimalarial agents. Chloroquine, an temperature of $26 \pm 4^{\circ} \mathrm{C}$ and a period of 12antimalarial drug, has been discovered to hour light and 12 hour darkness was have negative effects on sperm motility and maintained. The rats were fed standard ration fertility as a whole (Okanlawon et al., (Vital Feeds Limited, Ibadan) and clean water 1993); quinine is also known to inhibit ad libitum.

spermatogenesis (Osinubi et al., 2004).Plant material

Furthermore, pyrimethamine was observed The leaf of Acalypha wilkesiana was harvested to arrest spermatogenesis and cause within the campus of the Federal University of infertility in a dose-dependent manner. Agriculture, Abeokuta, Ogun State. Cessation of administration of the Identification and authentication was done at aforementioned drugs resulted in full the Forestry Research Institute of Nigeria restoration to normal fertility status

(Awoniyi et al., 1993; Consentino et al., Plant extraction

1990). Many medicinal plants have also

been reported to have antispermatogenic

effects. Alstonia boonei, a tropical plant, reputed in traditional medicine to have antimalarial, antipyretic, analgesic and anti-inflammatory properties (Ojewole, 1984; Olajide et al., 2000) was reported to cause dose dependent changes in the body weight, organ weights and sperm characteristics in male rats. Azadirachta indica, another medicinal plant with very potent antiplasmodial activities in mice, has also been reported to cause mass atrophy of spermatogenic elements and Leydig cells (Gbile, 1986).

There has not been any documented report The plant extraction was done as described by (Iwu and Igboko, 1982; Iwu 1985). Briefly, the leaf of Acalypha wilkesiana was air dried, pulverized, finely sieved and $500 \mathrm{~g}$ of the plant was soaked in 1 litre of distilled water for 24 hours after which it was filtered. Thereafter, the filtrate was evaporated to dryness and $1 \mathrm{~g}$ of it was dissolved in $20 \mathrm{mLs}$ of distilled water to give a concentration of $50 \mathrm{mg} / \mathrm{mL}$. Experimental procedure

The rats were randomly assigned into four groups (A-D) of 6 rats each. The rats in groups $\mathrm{A}, \mathrm{B}$ and $\mathrm{C}$ were given aqueous extract of the leaf of Acalypha wilkesiana at 400, 800 and $1600 \mathrm{mg} / \mathrm{kg}$ body weight,

on the effect of the leaf extract of Acalypha

Olukunle, Jacobs, Adeleye, Oyewusi, Adenubi. and Durotoye 
respectively once daily orally for 28 days. Group D rats were the control to which 5 $\mathrm{mLs} / \mathrm{kg}$ distilled water was administered orally once daily for 28 days. Thereafter, the rats were euthanized by placing them in a glass chamber containing cotton wool soaked in diethyl ether till they lost consciousness followed by cervical dislocation. A ventral midline abdominal incision was then made using a scalpel blade size 14 to expose the abdominal organs. The testis and epididymis of each rat were identified, carefully removed and a small incision was made on the caudal epididymis to squeeze out the semen content on a glass slide for semen evaluation. The testis and epididymis were thereafter preserved in Bouins fluid for histopathological evaluation.

\section{Statistical analysis}

Data were subjected to ANOVA package of SAS (1999) and means were separated using DMRT of the same software at $\mathrm{P}<0.05$

$\begin{array}{lccl}400 \mathrm{mg} / \mathrm{kg} & 80.00 \pm 7.0 & 96.00 \pm 2.0 & 82.75 \pm 2.7 \\ 800 \mathrm{mg} / \mathrm{kg} & 75.00 \pm 2.9 & 94.50 \pm 1.7 & 76.50 \pm 3.8 \\ 1600 \mathrm{mg} / \mathrm{kg} & 85.00 \pm 5.0 & 96.50 \pm 0.9 & 71.50 \pm 3.5^{*} \\ \text { Control } & 93.75 \pm 1.3 & 98.00 \pm 0.0 & 129.00 \pm 5.0\end{array}$

Table 1 : Effects of Acalypha wilkesiana aqueou s extract on serum characteristic of rats

\begin{tabular}{llll}
\hline ACALYPHA & SPERM MOLITY & LIVE/DEAD & SPERM COUNTS \\
WILKESIANA & & \\
\hline
\end{tabular}

\section{Results}

Acalypha wilkesiana leaf extract at the dosages $400 \mathrm{mg} / \mathrm{kg}$ and $800 \mathrm{mg} / \mathrm{kg}$ did not cause any significant change in the percentage life sperm cells/ death ratio $(96.00 \pm 2.0,94.50 \pm 1.7)$, sperm motility $(80.00 \pm 7.0,75.00 \pm 2.9)$, and sperm count of the treated rats when compared with the control (Table 1). However, at the dosage of $1600 \mathrm{mg} / \mathrm{kg}$, there was a decrease in the sperm count of the Wistar rats following oral administration of aqueous extract of $A$. wilkesiana leaves. The decrease in sperm count value of $(71.50 \pm 3.5)$ in the group dosed with $1600 \mathrm{mg} / \mathrm{kg}$ is statistically significant at $(\mathrm{P}<0.05)$ when compared with the control (Table 1).

At the dose of $400 \mathrm{mg} / \mathrm{kg}$, statistically significant $\quad(\mathrm{P}<0.05) \quad$ increases were observed in the values of bent tail (3796.3 \pm 274.9$)$ and curved tails

(3519.0 \pm 268.2$)$ when compared to the control (Table 2). 
There was no significant $(\mathrm{P}<0.05)$ change in the morphology of spermatozoa in the group treated with $800 \mathrm{mg} / \mathrm{kg}$ when compared with the control except in the curved tail $(3517.25 \pm 269.2)$ which is statistically higher $(\mathrm{P}<0.05)$ than the control (Table 2$)$. However, at $1600 \mathrm{mg} / \mathrm{kg}$ dose, there were significant increases $(\mathrm{P}<0.05)$ in the values observed in headless tail $(239.3 \pm 27.3)$, tailless head

(239.25 \pm 27.6$)$, bent tail $(4157.0 \pm 475.45)$, curved tail $(4099.3 \pm 260.0)$ and curved midpiece (4557.5 \pm 259.3$)$ compared to the Control. Others like rudimentary tail $(18.50+2.5)$, be n t midpiece
$(4379.00+388.0)$ and looped tail $(16.00+2.9)$ did not exhibit any statistically significant $\quad(\mathrm{P}<0.05) \quad$ changes when compared to the control values (Table 2). Histopathology of the testis and epididymis rats administered 400 and $800 \mathrm{mg} / \mathrm{kg}$ doses of aqueous leaf extract of A. wilkesiana revealed no significant lesion, except the group dosed with $1600 \mathrm{mg} / \mathrm{kg}$ which had various degrees of lesions in the testis including spermiostasis, degeneration and necrosis of the germinal epithelial cells of the seminiferous tubules (Figures 1 and 2). At $1600 \mathrm{mg} / \mathrm{kg}$ body weight, the following lesion was observed: 


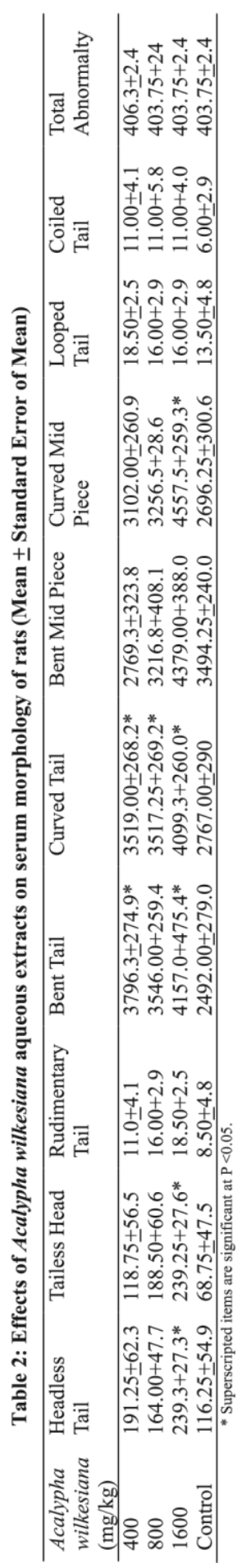


Olukunle, Jacobs, Adeleye, Oyewusi, Adenubi. and Durotoye

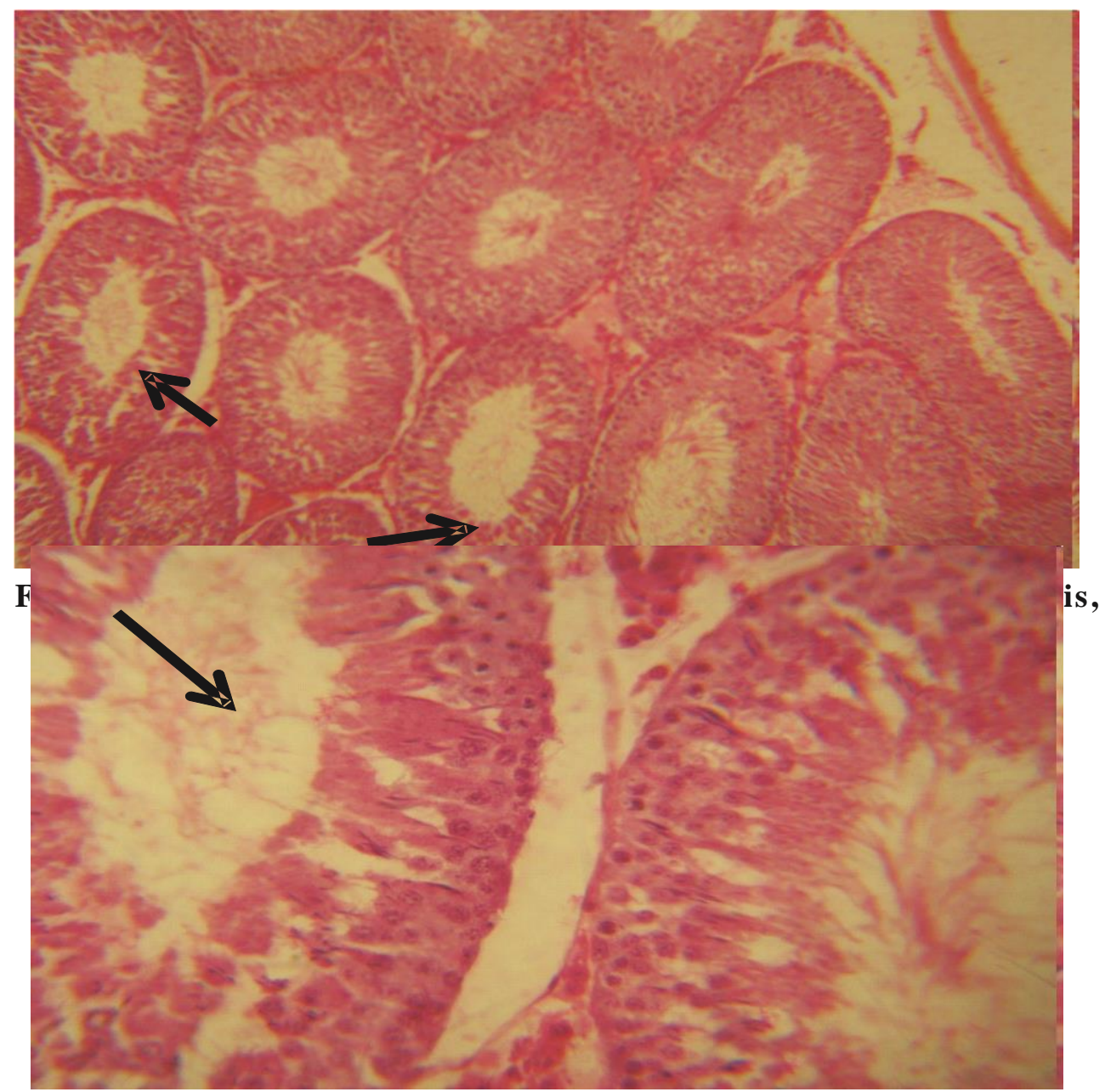

Figure 2: Enlarged photomicrograph of the testis showing

degeneration and necrosis of the germinal epithelial cells of the seminiferous tubules (arrows). Hand E. X 200.

spermiostasis of the germinal epithelial cells of the seminiferous

tubules (arrow) H \& E, X450. sperm count. Some secondary morphological sperm abnormalities such

\section{Discussion}

Administration of the doses of aqueous leaf extract of Acalypha wilkesiana (400, 800 and $1600 \mathrm{mg} / \mathrm{kg}$ ) did not cause any change in progressive sperm motility, percentage sperm live/dead ratio and as headless tail, bent tail and curved midpiece were significantly higher in the $1600 \mathrm{mg} / \mathrm{kg}$ treated rats, this may be due to the presence of high level of the phytochemicals with antispermatogenic tendency in the extract of Acalypha 
wilkesiana used at extra- pharmacological dosage. Also there were obvious testicular lesions observed at $1600 \mathrm{mg} / \mathrm{kg}$ dose of the extract (Figures 1 and2) which are sequela of the effects of the antispermatic phytochemicals.

The leaf extract of Acalypha wilkesiana is believed to have a wide safety margin. It was observed that oral administration of extract of A. wilkesiana up to $3000 \mathrm{mg} / \mathrm{kg}$ with LD50 of $2828.34 \mathrm{mg} / \mathrm{kg}$ to rats neither showed mortality nor any apparent signs of weakness in the animals (Olukunle et al., 2015). However, in this study, three doses; 400,800 and $1600 \mathrm{mg} / \mathrm{kg}$ were tested. There were usually multiple doses of $400 \mathrm{mg} / \mathrm{kg}$ of the extract mostly used by herbal practitioners.

Sperm motility depends on the coordinated propagated flagella wave under acetylcholinesterase control (Nelson, 1972). Fructose utilization and glucose oxidation are important means by which spermatozoa derive energy for their motility. The reduction in the progressive sperm motility of the treated rats seen in this $\mathrm{s} t \mathrm{ud} \mathrm{y} \mathrm{cou} \mathrm{ld}$ be d u e t o t h e

acetylcholinesterase inhibition and glucose lowering properties of the species of this plant (Nelson, 1972).

Since several studies have reported the antifertility effects of antimalarial agents, this result is in consonance with previous studies on chloroquine, quinine and quinacrine all of which have been reported to inhibit Leydig cell steroidogenesis and fertility in the male (Adeeko and Dada, 1998).

\section{Conclusion and recommendation}

In conclusion, this study shows that daily oral administration of $1600 \mathrm{mg} / \mathrm{kg}$ body weight of Acalypha wilkesiana leaf extract for a period of 28 days has tendency to exhibit anti-spermatogenic effects in adult male Wistar rats as seen with most other anti-malarial herbs. Further studies aimed at elucidating the mechanism of activity of Acalypha wilkesiana extract would be worthwhile.

\section{References}

Adesina, S. K., Idowu, O., Ogundaini, A., Oladimeji, H., Olugbade, T. A., Onawunmi, G. O., Akinde, B. E. and Odeyemi, O. O. 1987.

Extraction and Microbiological Evaluation of oils from the leaves of Acalypha Wilkesiana. Nigerian Med. Journal 38: 147-158.

Akinde, B. E. and Odeyemi, O. O. 1987. Extraction and microbiological evaluation of the oils from the leaves of Acalypha wilkesiana. Nigerian Medical Journal 17:163-165.

Akinyemi, K. O., Oluwa, O. K. and Omomigbehin 2006. African Jo urna lof Tradition a Complimentary and Alternative Medicines, 3, 4-12.

Awoniyi, C. A., Chandrashekar, V., Hurst, B. S., Kim, W. K., Schlaff, W. D., 1993. The effects of chronic administration of pyrimethamine on spermatogenesis and fertility in male rats. Journal of Andrology. 14 (3): 174-179.

Burkill, H. M. 1985. The Useful Plants of West Tropical Africa, Vol. 2. 2nd ed. Royal Botanic Garden, Keaw, London, p. 127.

Bussing, A., Stein, G. M., HerterichAkinpelu, I., Pfuller, U. 1999. Apoptosis-associated generation of reactive oxygen intermediates and release or proinflammatory cytokines in human lymphocytes and granulocytes by extracts from the seeds of Acalypha 
wilkesiana. Journal of Ethnopharmacology 66, 301-309.

Cosentino, M. J., Ruth, E., Fried, J. 1990. Pyrimethamine; An approach to the investigation into the effect of chloroquine on fertility of male rats. West. African. Journal of Medicine. 12:118-121.

\section{Olukunle, Jacobs, Adeleye, Oyewusi, Adenubi. and Durotoye}

$\mathrm{d}$ e v e 1 o p m e n t of a m a 1 e contraceptive. Proceedings of National Academy of Science. USA, 87: 1431-1435.

Gbile, Z. O. 1986. Medicinal plant research in Nigeria. Proceedings of workshop on state of medicinal research in Nigeria. Sofowora, A. (Ed). Ife University Press. 21.

Hirano, T., Kokka and Akiba M. 1989. Effects of Synthetic and natural flavonoids on $\mathrm{Ng}$, K-ATPase; Aspect of the structure relationship and action mechanism Life

Science; 45: 1111-1117.

Ikewuchi, J. C., Anyadiegwu, A., Ugono, E. Y. and Okungbowa, S. O. 2008. Effects of Acalypha Wilkesiana Muell Arg on Plasma Sodium and Potassium Concentration of Normal Rabbits. Pakistan Journal of Nutrition 7 (1): 130-132, 2008.

Kokko, J. P. 1984. Site and Mechanism of action of Diuretics. American Journal of Medicine 77:11-17

Nelson, L. 1972. Quantitative evaluation of s perm motili t y con trol mechanisms. Biology of. Reproduction. 6:319-324.

Ojewole, J. A. O. 1984. Studies on the pharmacology of Echitamine, an alkaloid from the stem bark of Alstonia boonei. L International Journal Crude Drug Research 22: 121-143.

Okanlawon, A. O., Noronha, C. C., Ashiru, O. A. 1993. An
Olajide, O. A., Makinde, J. M. Okpako, D. T. and Awe, S. O. 2000. Studies on the anti-inflammatory and related pharmacological properties of the aqueous extract of Bridelia ferruginea stem bark. Journal of Ethnopharmacology 71:153-160.

Osinubi, A. A., Akinola, J. T., Agbaje, M. A., Okanlawon, A. O., Noronha, C. C. 2004. Effects of short term administration of quinine on the seminiferous tubules of SpragueDawley rats. Nigeria Journal of Health and Biomedical Sciences 3(1): 1-7.

Oladunmoye, M. K. 2006. Comparative Evaluation of Antimicrobial Activities and Phytochemical screening of two varieties of Acalypha wilkesiana. Trends in applied sciences Research 1(5); 538-541.

Olukunle J. O., Jacobs, E. B., Ajayi, O. L. and Biobaku, K. T.. 2015. Toxicological evaluation of the aqueous extract of Acalypha wilkesiana in Wistar albino rats. Journal of Complementary and In $\mathrm{t}$ e g r a t i ve M e d i c i n e (DGJCIM)10(1): 12(1):53-56, $2 \quad 0 \quad 1 \quad 4$

http://www.degruyter.com/view/ jcim.2015. 12 .issue-1/jcim -2.

Onawunmi, G. O. 2003. Clinical evaluation of Acalypha ointment in the treatment of superficial fungal 
skin diseases. Phytotherapy

Research 17, 555-557.

Oyelami, O. A., Onayemi, O., Oladimeji, F. A., Ogundaini, O. A.,

Olugbade, T. A., Pais, M. 2000.

Antimicrobial constituents of the leaves of Acalypha wilkesiana and Acalypha hispida. Phytotherapy Research 14, 371-374.

Antispermatogenic activity of leaf extract of Acalypha wilkesiana

Vogler, B. K. and Ernst, E. 1999. "Aloe Vera: A Systematic Review of Its Clinical Effectiveness". British Journal of General Practice 49 (447): 823-8. PMID10885091

Received: 12th July, 2018

Accepted: 9 ${ }^{\text {th }}$ February, 2019 